
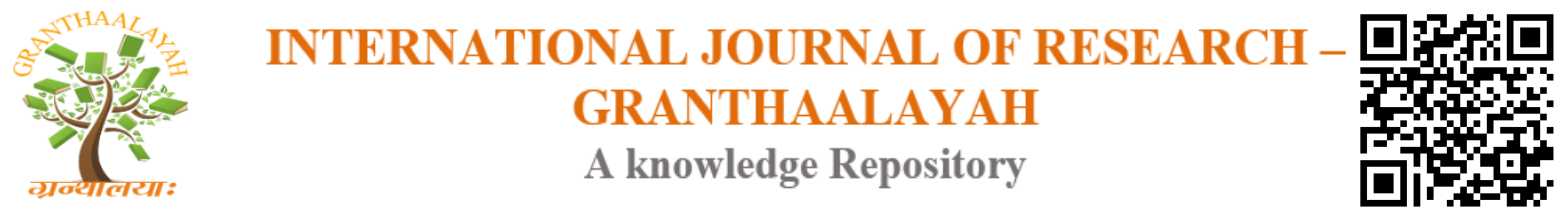

Social

\title{
A STUDY ON ANXIETY AND ITS EFFECTS ON READING SKILLS
} AMONG BED TRAINEES

\author{
N. Pavithra ${ }^{1}$, Mrs. J. Vanitha ${ }^{2}$ \\ ${ }^{1}$ MEd Scholar, RVS College of Education, India \\ ${ }^{2}$ M.Sc., M. Phil., M.Ed., M.Phil (Edn)., PGDCA., Assistant Professor in Pedagogy of \\ Mathematics RVS College of Education, India
}

\begin{abstract}
It is a matter of great concern for the future society to witness the widely increasing array of psychological problems, like, academic stress, anxiety and depression. Every nation invests lot of money on education. Research survey on students 'reports that at any given time there will be 10 to 20 percent of student population suffering from severe mental problems like stress, anxiety, depression, or emotional conflicts, who require immediate professional assistance. We often get to hear that people of different age groups, especially students going through depression. Anxiety, stress, insecurity seems to be building up from a tender age; seeds so sown crop up into big trees in the later lives. Students are so much arrested by anxiety, insecurity that under severe conditions they don't even hesitate opting to commit suicide. The reason being, non-achievement of the desired goals or due to the firm faith in failure, greater academic demands, changes in family expectations, changes in social life, exposure to new environment, people, ideas and temptations. The paper is an attempt to identify anxiety in reading skill among B.Ed trainees.
\end{abstract}

Keywords: Reading Skill; B.Ed Trainees; Level Of Anxiety; Reading Difficulty; Simple Random Sampling.

Cite This Article: N. Pavithra, and Mrs. J. Vanitha. (2019). "A STUDY ON ANXIETY AND ITS EFFECTS ON READING SKILLS AMONG BED TRAINEES." International Journal of Research - Granthaalayah, 7(5), 357-360. 10.29121/granthaalayah.v7.i5.2019.857.

\section{Introduction}

Anxiety is an emotional state in which people feel uneasy, apprehensive, or fearful. People usually experience anxiety about events they cannot control or predict, or about events that seem threatening or dangerous. There is a feeling of vulnerability, and severe anxiety can persist and become disabling. English also plays an important role in education and students are expected to use it effectively. English is necessary for all professions. However, proper learning of English in the world is challenging. Many students are able to understand the language, but most of the students face the problem of communicating their ideas effectively. The problem is the lack of both: the adequate stock of English vocabulary and creativity in writing. It is evident that writing 
is the biggest challenge for many students. The paper is an attempt to identify anxiety in reading skill among B.Ed trainees. The investigator adopted the survey method to study anxiety of B.Ed trainees. The study is based on primary data which was collected from 300 BEd trainees in and around Coimbatore district using simple random sampling technique. The findings reveal that totally $25.66 \%$ of the selected B.Ed trainees belong to low level of anxiety, $48 \%$ of the selected B.Ed trainees belong to moderate level of anxiety, $26.33 \%$ of the selected B.Ed trainees belong to high level of anxiety. Thus, it is inferred that there is a difference in the level of anxiety among selected B.Ed. trainees. Also it is found that there is no significant effect on reading skills among the selected B.Ed trainees in Coimbatore district.

\section{Research Design}

The study aimed to identify the anxiety and its effects in reading among B.Ed trainees. In the present study survey method was usedThe study is based on primary data which is collected from 300 B.Ed trainees in and around Coimbatore district.

\section{Hypothesis: 1}

There is no difference in the level of anxiety among selected B.Ed Trainees.

Table 1: Frequency and percentage difference in the level of anxiety among the selected B.Ed. Trainees.

\begin{tabular}{|c|c|c|c|c|c|c|c|c|}
\hline \multicolumn{10}{c|}{ ANXIETY } \\
\hline \multicolumn{3}{|c|}{ Low } & \multicolumn{3}{c|}{ Moderate } & \multicolumn{3}{c|}{ High } \\
\hline Q1 & F & \% & Q2 & F & \% & Q3 & F & \% \\
\hline 109 & 77 & $25.66 \%$ & 118 & 144 & $48 \%$ & 128 & 79 & $26.33 \%$ \\
\hline
\end{tabular}

Table :1 exhibits the result of anxiety among selected B.Ed. Trainees. According to the table, totally $25.66 \%$ of the selected B.Ed trainees belong to low level of anxiety, $48 \%$ of the selected B.Ed trainees belong to moderate level of anxiety, $26.33 \%$ of the selected B.Ed trainees belong to high level of anxiety. So the hypothesis is rejected. Thus it is inferred that there is a difference in the level of anxiety among selected B.Ed trainees.

\section{Hypothesis: 2}

There is no difference in the level of difficulties in reading skill among the selected B.Ed Trainees.

Table 2: Frequency and percentage difference in the level of difficulties in reading skill among the selected B.Ed trainees.

\begin{tabular}{|c|c|c|c|c|c|c|c|c|}
\hline \multicolumn{10}{|c|}{ READING SKILL } \\
\hline \multicolumn{3}{|c|}{ Low } & \multicolumn{3}{c|}{ Moderate } & \multicolumn{3}{c|}{ High } \\
\hline Q1 & F & \% & Q2 & F & \% & Q3 & F & \% \\
\hline 10 & 78 & $26 \%$ & 18 & 79 & $26.33 \%$ & 20 & 143 & $47.66 \%$ \\
\hline
\end{tabular}

Table: 2 exhibits the result of difficulties in reading skill among the selected B.Ed trainees. According to the table, totally $26 \%$ of the selected B.Ed trainees belong to low level of difficulties in reading skill, $26.33 \%$ of the selected B.Ed trainees belong to moderate level of difficulties in reading skill, $47.66 \% \%$ of the selected B.Ed trainees belong to high level of difficulties in reading 
skill. So, the hypothesis is rejected. Thus it is inferred that there is a difference in the level of difficulties in reading skill among the selected B.Ed trainees.

\section{Hypothesis: 3}

There is no significant effect of anxiety on reading skill among selected B.Ed. trainees.

Table 3: Model Summary

\begin{tabular}{|c|c|c|c|c|}
\hline Model & R & R Square & Adjusted R Square & Std. Error of the Estimate \\
\hline 1 & $.125^{\text {a }}$ & .016 & .012 & 5.379 \\
\hline \multicolumn{2}{|l|}{ a. Predictor: (Constant), Language Anxiety } \\
\hline
\end{tabular}

From the above table, $\mathrm{R}$ indicates the correlation between the observed and the predicted value of the dependent variable personality which is 0.125 . R Square indicates the proportion of the variance in the dependent variable namely, reading skill that is explained by the effect of the independent variable namely anxiety.

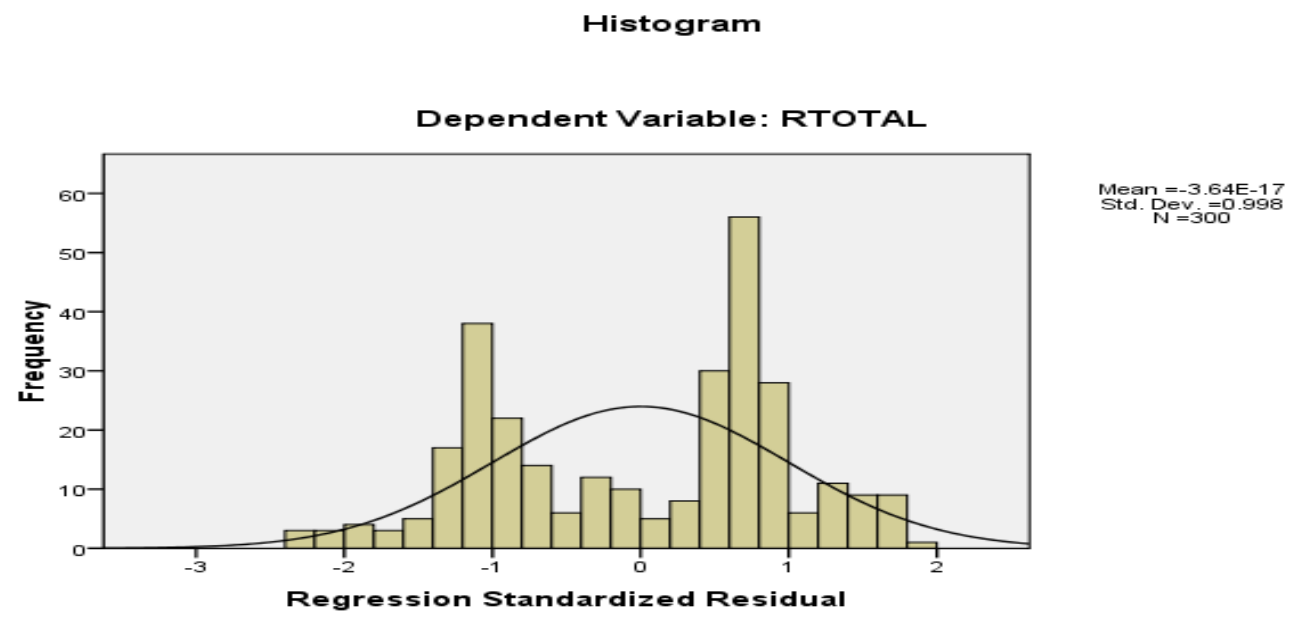

Chart 1: Histogram

The above histogram shows that the distribution is normal, which is a basic requirement for regression analysis.

Table 4: ANOVA

\begin{tabular}{|l|l|l|l|l|c|c|}
\hline \multicolumn{7}{|c|}{ ANOVA } \\
\hline \multicolumn{1}{|c|}{ Model } & Sum of Squares & df & Mean Square & F & Sig. \\
\hline 1 & Regression & 136.628 & 1 & 136.628 & 4.722 & $.031^{\mathrm{a}}$ \\
\hline & Residual & 8623.119 & 298 & 28.937 & & \\
\hline Total & 8759.747 & 299 & & & \\
\hline $\begin{array}{l}\text { a. Predictors: Constant - Anxiety, Language } \\
\text { b. Dependant Variable - Reading skill }\end{array}$ \\
\hline
\end{tabular}


In the above table, the sum of squares associated with the three-variance regression, residuals and the total. The total variance is partitioned into regression (136.628) and residuals (8623.119) which indicate the variance explained by the independent variables and the variance not explained by the independent variables.

The F value is statistically significant at 0.05 level. It suggests that there exists linear relationship among the variables. Hence, the hypothesis is rejected, and it is concluded that there is a significant effect of anxiety on reading skill among selected B.Ed. trainees.

\section{Conclusion}

The findings reveal that totally $25.66 \%$ of the selected B.Ed trainees belong to low level of anxiety, $48 \%$ of the selected B.Ed trainees belong to moderate level of anxiety and $26.33 \%$ of the selected B.Ed trainees belong to high level of anxiety. Also $26 \%$ of the selected B.Ed trainees belong to low level of difficulties in reading skill, $26.33 \%$ of the selected B.Ed trainees belong to moderate level of difficulties in reading skill and $47.66 \% \%$ of the selected B.Ed trainees belong to high level of difficulties in reading skill. It is concluded that there is a significant effect of anxiety on reading skill among selected B.Ed trainees.

\section{References}

[1] Kasztalska, A. (2014). English in contemporary Poland. World Englishes, 33(2), 242-262. Kilickaya, F. (2009). World Englishes, English as an international language and applied.

[2] Golden, S. A. R. (2016). Rural Students' Attitude towards English as Medium of Instruction in Higher Education-An Analysis. International Journal of Research, 3, 1-10.

[3] Leonard, S. T., \& Winsauer, P. J. (2011). The effects of gonadal hormones on learning and memory in male mammals: a review. Current Zoology, 57(4), 543-558.

[4] Regi, S. B., \& Golden, S. A. R. (2014). A Study on Educational Loan Availed By Students in Trichy City. Journal of International Academic Research for Multidisciplinary (Jiarm), 2(1).

[5] Shank, R. (2006). 'Blended e-Learning. on line, date accessed, 15(11), 2007.

[6] Golden, S. A. R., \& Regi, S. B. Mobile Learning: A Transformative Tool for Learning and Education. 